\section{Penicillin Allergy: The Impact of a False Diagnosis}

\author{
Alergia à Penicilina: O Impacto de um Falso \\ Diagnóstico
}

Keywords: Drug Hypersensitivity; False Diagnosis; Penicillins/ adverse effects; Penicillins/immunology

Palavras-chave: Hipersensibilidade a Medicamentos; Penicilina/ efeitos adversos; Penicilina/imunologia

\section{To the Editor}

Penicillin is commonly involved in immediate and late drug hypersensitivity reactions. However, the rate of self-reported allergy largely exceeds the true allergy frequency. The false diagnosis results in worse consequences than initially

Table 1 - Demographics, infectious diseases requiring antibiotic therapy and antibiotics used as alternative and the allergy history of hospitalized patients that claimed to be allergic to penicillin $(n=40)$

\begin{tabular}{|c|c|}
\hline Age (mean $\pm S D$, years) & $75.6 \pm 11.4$ \\
\hline Data & $\begin{array}{c}\text { Number of } \\
\text { patients }\end{array}$ \\
\hline $\begin{array}{l}\text { Gender } \\
\text { » male } \\
\text { » female }\end{array}$ & $\begin{array}{l}12(30 \%) \\
28(70 \%)\end{array}$ \\
\hline $\begin{array}{l}\text { Inpatient diagnosis } \\
\text { " Colitis } \\
\text { " Urinary tract infection } \\
\text { " Respiratory infection } \\
\text { " Non-infectious }\end{array}$ & $\begin{array}{c}1(2.5 \%) \\
4(10 \%) \\
16(40 \%) \\
19(47.5 \%)\end{array}$ \\
\hline $\begin{array}{l}\text { Patients antibiotic therapy during hospitalization } \\
\text { »Ceftazidime } \\
\text { " Ceftriaxone } \\
\text { » Ceftriaxone+azithromycin } \\
\text { " Ceftriaxone+clarithromycin } \\
\text { » Cefuroxime } \\
\text { " Ciprofloxacin } \\
\text { » Levofloxacin } \\
\text { " Meropenem } \\
\text { » Metronidazole } \\
\text { " Piperacillin+tazobactam }\end{array}$ & $\begin{array}{c}1(2.5 \%) \\
3(7.5 \%) \\
5(12,5) \\
1(2.5 \%) \\
1(2.5 \%) \\
2(5 \%) \\
3(7.5 \%) \\
1(2.5 \%) \\
1(2.5 \%) \\
4(10 \%)\end{array}$ \\
\hline $\begin{array}{l}\text { Type of reaction } \\
\text { " Urticaria } \\
\text { » Exanthema } \\
\text { " Angioedema } \\
\text { " Other } \\
\text { " Cannot remember }\end{array}$ & $\begin{array}{l}3(7.5 \%) \\
8(20 \%) \\
5(12.5) \\
5(12.5) \\
19(47.5)\end{array}$ \\
\hline $\begin{array}{l}\text { Time since reaction } \\
\text { "< } 10 \text { years } \\
\text { " } 10 \text { to } 20 \text { years } \\
\text { " }>30 \text { years } \\
\text { "Cannot remember }\end{array}$ & $\begin{array}{c}5(12.5) \\
5(12.5) \\
26(65 \%) \\
4(10 \%)\end{array}$ \\
\hline $\begin{array}{l}\text { Allergy work-up result } \\
\text { » Not completed } \\
\text { » Negative } \\
\text { » Positive }\end{array}$ & $\begin{array}{c}24(60 \%) \\
14(35 \%) \\
2(5 \%)\end{array}$ \\
\hline
\end{tabular}

would be expected affecting the quality and raising the cost of healthcare services by $63 \% .^{1,2}$ Furthermore, the alternative antibiotics are, in most cases, second line alternatives, implying worse efficacy and inducing unnecessary bacterial resistances. ${ }^{2,3}$ In addition, this drug allergy is the easiest to confirm and the cost associated with the study is significantly lower than that associated with a false diagnosis. ${ }^{1,4}$

We conducted a study that included 680 patients hospitalized in the Internal Medicine department of a Portuguese district hospital, with 40 patients claiming to be allergic to penicillin. Table 1 shows data concerning the patients' demographics, infectious diseases requiring antibiotic therapy and antibiotics used as second-line treatment, as well as allergy history.

Sixty five percent of allergic reactions had occurred more than 30 years before and half of the patients could not describe the reaction. The most mentioned reaction was cutaneous (urticaria, angioedema or exanthema). Second or third generation cephalosporins were the most commonly chosen alternative to treat penicillin allergic patients, and were well tolerated in every case.

The allergy work-up confirmed the allergy in only two patients, thus showing that penicillin allergy is overreported by hospitalized patients in an Internal Medicine department. These results are in line with the international data that shows that penicillin allergy in hospitalized patients is only confirmed in $1 \%-10 \%$ of the cases. ${ }^{5}$ It is worth mentioning that 24 did not finish the work-up mainly due to poor mobility associated with age and chronic disease $(75.6 \pm 11.4$ years, with the majority suffering from chronic debilitating diseases).

It must be remembered that not only knowing the characteristics of the allergic reaction is essential in order to carry out an adequate allergy work-up but also that most people lose their penicillin allergy over time.

We highlight the need to confirm any suspected penicillin allergic reaction as early as possible. Clinicians in general and family physicians in particular should be aware of this need and not delay the opportunity to make an accurate diagnosis.

\section{REFERENCES}

1. Sade K, Holtzer I, Levo Y, Kivity S. The economic burden of antibiotic treatment of penicillin-allergic patients in internal medicine wards of a general tertiary care hospital. Clin Exp Allergy. 2003;33:501-6.

2. Sousa-Pinto $B$, Cardoso-Fernandes A, Araújo L, Fonseca JA, Freitas A, Delgado L. Clinical and economic burden of hospitalizations with registration of penicillin allergy. Ann Allergy Asthma Immunol. 2019;120:190-4.

3. Macy E, Contreras R. Health care use and serious infection prevalence associated with penicillin "allergy" in hospitalized patients: a cohort study. J Allergy Clin Immunol. 2014;133:790-6.

4. Macy E, Ngor EW. Safely diagnosing clinically significant penicillin allergy using only penicilloyl-poly-lysine, penicillin, and oral amoxicillin. J Allergy Clin Immunol Pract. 2013;1:258-63.

5. Mirakian R, Leech SC, Krishna MT, Richter AG, Huber PA, Farooque S, et al. Management of allergy to penicillins and other beta-lactams. Clin Exp Allergy. 2015;45:300-27.

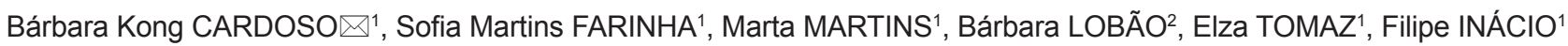

1. Serviço de Imunoalergologia. Centro Hospitalar de Setúbal. Setúbal. Portugal.

2. Serviço de Medicina Interna. Centro Hospitalar de Setúbal. Setúbal. Portugal.

$\triangle$ Autor correspondente: Bárbara Kong Cardoso. barbarakc@ gmail.com

Recebido: 19 de agosto de 2019 - Aceite: 02 de setembro de 2019 | Copyright $\odot$ Ordem dos Médicos 2019

https://doi.org/10.20344/amp.12717 